\title{
FAKTOR INTRINSIK YANG MEMPENGARUHI MOTIVASI PETANI JAHE PADA MASA PANDEMI COVID-19 DI KECAMATAN PORSEA KABUPATEN TOBA
}

\section{INTRINSIC FACTORS AFFECTING THE MOTIVATION OF GINGER FARMERS DURING THE COVID-19 PANDEMIC IN PORSEA DISTRICT, TOBA REGENCY}

\author{
Wella Tessalonika Ambarita*, Nur Syamsiyah, Trisna Insan Noor, \\ Sulistyodewi Nur Wiyono
}

\author{
Program Studi Agribisnis, Fakultas Pertanian, Universitas Padjadjaran \\ Jl. Raya Bandung-Sumedang KM. 21, Jatinangor 45363 \\ *Email: wella17001@mail.unpad.ac.id \\ (Diterima 04-10-2021; Disetujui 15-12-2021)
}

\begin{abstract}
ABSTRAK
Jahe (Zingiber officinale) merupakan salah satu tanaman obat yang memiliki banyak manfaat bagi kesehatan. Pada masa pandemi COVID-19, permintaan jahe di pasar mengalami peningkatan. Oleh sebab itu, produksi jahe harus ditingkatkan agar dapat memenuhi permintaan konsumen. Tingkat produksi berhubungan dengan motivasi petani dalam mengembangkan usahataninya. Motivasi merupakan kondisi yang mendorong seseorang untuk melakukan suatu tindakan yang dapat dipengaruhi oleh faktor dari dalam diri (faktor intrinsik). Tujuan dari penelitian adalah mengetahui faktor intrinsik yang mempengaruhi motivasi petani jahe pada masa pandemi COVID-19. Penelitian ini menggunakan desain kualitatif dengan metode survei. Penentuan lokasi penelitian menggunakan teknik purposive. Penelitian dilakukan di Desa Amborgang dan Desa Nalela atas pertimbangan sebagai daerah sentra produksi jahe di Kecamatan Porsea. Populasi penelitian adalah petani jahe dengan jumlah 160 orang. Sampel penelitian diambil menggunakan teknik probably sampling. Jumlah sampel sebanyak 62 orang yang terdiri atas 41 orang dari Desa Amborgang dan 21 orang dari Desa Nalela. Pengumpulan data dilakukan dengan obeservasi, wawancara, dan dokumentasi. Teknik analisis yang digunakan adalah analisis deskriptif. Responden didominasi oleh umur produktif sekitar 95,16 persen, jenis kelamin laki-laki sekitar 93,55 persen, lulusan pendidikan tingkat SLTA sekitar 58,06 persen, dan pekerjaan utama sebagai petani sekitar 77,42 persen. Hasil penelitian menunjukkan bahwa faktor intrinsik berada pada kategori sedang dengan persentase skor sebesar 55,16 persen. Variabel pendidikan formal dan pengalaman berada pada kategori tinggi; variabel umur, pendapatan, luas lahan, dan jumlah tanggungan keluarga berada pada kategori sedang; dan variabel pendidikan non formal berada pada kategori rendah.
\end{abstract}

Kata kunci: Faktor motivasi, Petani jahe, COVID-19

\begin{abstract}
ABSTRCT
Ginger (Zingiber officinale) is a medicinal plant that has many health benefits. During the COVID19 pandemic, the demand for ginger in the market has increased. Therefore, ginger production must be increased to supply consumer demand. High production is inseparable from the motivation of farmers to develop their farming. Motivation is a condition that encourages a person to take an action that is influenced by internal factors (intrinsic factors). The purpose of this study was to determine the intrinsic factors that influence the motivation of ginger farmers during the COVID19 pandemic. This study uses a qualitative design with a survey method. The location of the research was determined using a purposive technique. The research was conducted in Amborgang Village and Nalela Village for consideration as a center for ginger production in Porsea District. The research population is ginger farmers with a total of 160 people. The research sample was taken using probability sampling technique. The number of samples was 62 people consisting of 41 people from Ambogang Village and 21 people from Nalela Village. Data collection is done by
\end{abstract}


FAKTOR INTRINSIK YANG MEMPENGARUHI MOTIVASI PETANI JAHE

PADA MASA PANDEMI COVID-19 DI KECAMATAN PORSEA KABUPATEN TOBA

Wella Tessalonika Ambarita, Nur Syamsiyah, Trisna Insan Noor, Sulistyodewi Nur Wiyono

observation, interviews, and documentation. The analysis technique used is descriptive analysis. Respondents are dominated by productive age around 95.16 persen, male sex around 93.55 persen, high school education graduates around 58.06 persen, and main occupation as farmers around 77.42 persen. The results showed that the intrinsic factor was in medium category with a score percentage is 55.16 persen. The variables of formal education and experience are in high category; variables of age, income, land area, and number of family are in medium category; and variable of non-formal education is in low category.

Keywords: Motivation factors, Ginger farmers, COVID-19

\section{PENDAHULUAN}

Coronavirus disease 2019 atau COVID-19 merupakan penyakit pernapasan akut yang disebabkan oleh SARS-CoV-2 (Severe Acute Respiratory Syndrome Corona Virus 2) yaitu virus corona versi terbaru yang muncul di akhir tahun 2019 dan diduga bermula dari kota Wuhan, China (Guo, et al, 2020). Virus ini memiliki sifat penyebaran yang sangat cepat dan menyerang sistem pernapasan manusia hingga berisiko pada kematian. COVID-19 dapat tersebar melalui udara ataupun dengan objek yang telah terpapar virus (British Medical Association, 2020). Nurlila \& Fua (2020) menjelaskan bahwa sistem imun tubuh adalah hal yang sangat penting untuk dijaga dalam menghadapi situasi pandemi COVID-19 saat ini. Munadi (2017) menyatakan bahwa konsumsi tanaman obat dapat membantu meningkatkan sistem kekebalan tubuh karena memiliki kandungan metabolit sekunder seperti gingiro pada tanaman jahe sehingga memiliki sifat pencegahan (preventif).
ÇİFCI, et al. (2018) menyatakan bahwa jahe adalah salah satu rempah yang bermanfaat banyak bagi kesehatan dan dapat digunakan untuk mengobati penyakit pernapasan. Jahe secara efisien dapat mengurangi dan melindungi paruparu dari kerusakan akibat hiperoksia (kadar oksigen yang berlebih dalam sel dan jaringan tubuh) dan inflamasi (peradangan). Pemintaan jahe di masa pandemi COVID-19 mengalami peningkatan drastis dikarenakan keyakinan masyarakat akan manfaat besar jahe bagi kesehatan khususnya peningkatan imunitas tubuh selama pandemi COVID-19 (Kusumawanti, 2020).

Indonesia adalah salah satu negara agraris yang berpotensi untuk menghasilkan jahe dalam jumlah besar karena memiliki iklim tropis yang dapat mendukung pertumbuhan tanaman jahe dengan baik (Pramudya, 2016). Produksi terakhir jahe Indonesia pada tahun 2020 mencapai 179.043 ton (BPS, 2021). Provinsi Sumatera Utara adalah salah 
satu daerah penghasil jahe di Indonesia. Rata-rata produksi jahe Provinsi Sumatera Utara dalam lima tahun terakhir adalah sebesar sekitar 6.320 ton dengan tingkat produktivitas yang fluktuatif tiap tahunnya (BPS, 2019, 2021). Kabupaten Toba merupakan salah satu sentra produksi jahe di Provinsi Sumatera Utara, dimana pada tahun 2020 Kabupaten Toba berhasil meningkatkan jumlah produksi sebesar 69,61 persen (BPS, 2021). Kecamatan Porsea merupakan salah satu bagian dari Kabupaten Toba yang berpotensi untuk mengembangkan komoditas jahe dengan rata-rata jumlah produksi dari tahun 2016 hingga tahun 2020 mencapai 120,36 ton. Dalam lima tahun terakhir produksi jahe di Kecamatan Porsea mengalami fluktuasi. Produktivitas jahe pada tahun 2017 adalah sekitar 18,93 ton/ha yang mengalami peningkatan sebesar 7,75 persen dibanding tahun sebelumnya. Namun, pada tahun 2019 produktivitas jahe mengalami penurunan sebesar 16,86 persen. Selanjutnya, tahun 2020 produktivitas kembali mengalami peningkatan sebesar 4,67 persen dengan jumlah 16,47 ton/ha.

Produktivitas yang fluktuatif menggambarkan bahwa petani belum konsisten dalam menjalankan usahataninya. Peningkatan produksi ataupun produktivitas tidak terlepas dari motivasi petani dalam menjalankan usahataninya dimana semakin tinggi motivasi petani untuk berhasil dalam bertani, maka semakin tinggi juga produktivitas yang dapat dicapai petani tersebut (Ibrahim, dkk, 2012). Motivasi merupakan kondisi yang mendorong seseorang untuk melakukan suatu tindakan atas tujuan yang ingin dicapainya (Sofwan, et al., 2018). Proses pembentukan motivasi dapat dipengaruhi faktor-faktor yang berasal dalam diri seseorang. Pengaruh yang bersumber dari dalam diri individu dinamakan sebagai faktor intrinsik (Primadesi, 2010). Oleh sebab itu, sangat perlu diketahui faktor intrinsik yang mempengaruhi motivasi petani jahe di Kecamatan Porsea, Kabupaten Toba, Provinsi Sumatera Utara dalam menjalankan usahataninya.

\section{METODE PENELITIAN}

Penentuan lokasi penelitian menggunakan teknik purposive. Penelitian dilakukan di Desa Amborgang dan Desa Nalela, Kecamatan Porsea, Kabupaten Toba, Provinsi Sumatera Utara. Populasi dalam penelitian adalah seluruh petani yang membudidayakan jahe di lokasi penelitian dengan jumlah 
sebanyak 160 orang. Pengambilan sampel dilakukan menggunakan teknik probably sampling yang dihitung menggunakan rumus slovin dengan tolerasi kesalahan sebesar 10 persen sebagai berikut:

$n=\frac{N}{1+N\left(\alpha^{2}\right)}$

Keterangan:

$\mathrm{n}=$ Ukuran Sampel

$\mathrm{N}=$ Ukuran Populasi

$\boldsymbol{\alpha}=$ Sampling eror $(\boldsymbol{\alpha}=10$ persen $)$

Berdasarkan persamaan rumus slovin di atas, maka diperoleh jumlah sampel sebesar 62 petani. Dalam menentukan banyaknya sampel tiap desa maka digunakan teknik proportionate stratified random sampling dengan rumus sebagai berikut:

$n_{i}=\frac{N_{i}}{N} \times n$

Keterangan:

$n_{i}=$ jumlah sampel wilayah $\mathrm{i}$

$N_{i}=$ jumlah populasi wilayah $\mathrm{i}$

$\mathrm{N}=$ jumlah total populasi penelitian

$\mathrm{n}$ = jumlah sampel mewakili populasi

Berdasarkan persamaan rumus di atas maka dapat diketahui jumlah sampel yang diperlukan dari Desa Amborgang sebanyak 41 responden dan Desa Nalela sebanyak 21 responden. Desain pada penelitian adalah kuantitatif dengan metode survei. Teknik pengambilan data dengan observasi, wawancara dengan bantuan kuesioner, dan dokumentasi. Sementara itu, teknik analisis pada penelian adalah statistik deskriptif untuk mengetahui tingkatan faktor intrinsik dan ekstrinsik yang mempengaruhi motivasi petani jahe. Faktor intrinsik terdiri atas 7 variabel, yaitu: umur, pendidikan formal, pendidikan non formal, pengalaman, pendapatan, luas lahan, dan jumlah tanggungan keluarga. Sementara itu, faktor ekstrinsik terdiri atas 5 variabel, yaitu: lingkungan sosial, ketersediaan sarana produksi, ketersediaan lembaga permodalan, peran lembaga penyuluhan, dan jaminan informasi pasar. Data responden yang terkumpul dianalisis dengan mengitung jumlah skor dari skala likert yang ditetapkan berdasarkan rumus berikut:

$\%$ Skor $=\frac{\text { Total Skor yang Diperoleh }}{\text { Skor Maksimum yang Dicapai }} \times 100 \%$

Selanjutnya dilakukan interpetasi skor ke dalam 5 kategori, yaitu:

1. Apabila persentase skor berada pada angka $0 \%-20 \%$, maka variabel digolongkan kategori sangat rendah.

2. Apabila persentase skor berada pada angka 21\%-40\%, maka variabel digolongkan kategori rendah.

3. Apabila persentase skor berada pada angka 41\%-60\%, maka variabel digolongkan kategori sedang. 
4. Apabila persentase skor berada pada angka 61\%-80\%, maka variabel digolongkan kategori tinggi.

5. Apabila persentase skor berada pada angka $81 \%-100 \%$, maka variabel digolongkan kategori sangat tinggi.

\section{HASIL DAN PEMBAHASAN}

\section{Karakteristik Responden}

1. Umur Responden

Rata-rata umur responden adalah sekitar 43 tahun atau tergolong kategori usia produktif dengan umur termuda adalah 21 tahun dan umur tertua adalah 70 tahun. Responden yang berada pada kategori usia produktif (15-64 tahun) adalah sebanyak 95,16 persen, dan berdasarkan usia yang termasuk kategori usia tua ( $>64$ tahun) adalah sebanyak 4,84 persen. Dapat diketahui bahwa responden didominasi oleh umur produktif yang memungkinkan responden untuk menjalankan usahataninya lebih baik. Suherdi, dkk (2014) menyatakan bahwa petani yang berusia produktif akan lebih baik dalam menjalankan usahatani karena memiliki kondisi fisik yang masih kuat, didukung oleh tingkat pengetahuan dan kemampuan yang memadai, serta memiliki intensitas hubungan sosial yang lebih baik.
2. Jenis Kelamin Responden

Jenis kelamin responden dapat diklasifikasikan menjadi 2 jenis, yaitu laki-laki dan perempuan. Respoden didominasi oleh jenis kelamin laki-laki dengan persentase sebesar 93,55 persen. Sementara itu, responden berjenis kelamin perempuan hanya sekitar 6,45 persen. Menurut Restutiningsih et al (2016), bahwa penyebab terjadinya dominasi responden laki-laki dibanding responden perempuan adalah karena lakilaki memiliki peran penting sebagai kepala keluarga yang akan bertanggung jawab atas anggota keluarga yang dipimpinnya khususnya dalam memenuhi kebutuhan keluarga.

\section{Pendidikan Responden}

Pendidikan terakhir yang ditempuh responden terdiri atas tingkat sekolah dasar (SD), Sekolah Menengah Pertama (SMP), Sekolah Menengah Atas (SMA), Sekolah Menengah Kejuruan (SMK), dan Strata 1 (S-1). Sebagian besar responden penelitian menyelesaikan pendidikan formalnya pada tingkat SLTA (Sekolah Lanjutan Tingkat Atas) yaitu tingkat SMA dan SMK dengan persentase sebesar 58,06 persen. Jumlah responden yang lulus pada tingkat SMA adalah sebesar 40,32 persen dan 17,74 persen responden lulus pada tingkat SMK. 
FAKTOR INTRINSIK YANG MEMPENGARUHI MOTIVASI PETANI JAHE

PADA MASA PANDEMI COVID-19 DI KECAMATAN PORSEA KABUPATEN TOBA

Wella Tessalonika Ambarita, Nur Syamsiyah, Trisna Insan Noor, Sulistyodewi Nur Wiyono

Tingkat pendidikan terendah yang dicapai responden adalah tingkat SD dengan persentase sebesar 4,84 persen, dan tingkat SMP sebesar 30,65 persen. Sementara itu, tingkat pendidikan tertinggi yang dicapai responden adalah jenjang Strata-1 (S1) yaitu sebesar 6,45 persen. Managanta (2016) menyatakan bahwa pendidikan yang memadai akan memampukan petani untuk menyesuaikan diri dalam mengikuti perkembangan bidang pertanian.

\section{Pekerjaan Utama Responden}

Pekerjaan merupakan sesuatu yang dilakukan atau dikerjakan untuk dijadikan sebagai pokok penghidupan atau mendapatkan nafkah (Poerwadarminta, 2011). Sebanyak 77,42 persen responden memiliki pekerjaan utama sebagai petani. Sementara itu, sebanyak 22,58 persen responden memilih bertani jahe sebagai pekerjaan sampingan karena sebelumnya telah memiliki pekerjaan tetap. Walaupun demikian, responden tetaplah seorang petani dan kehidupan mereka tidak dapat terpisahkan dari kegiatan berusahatani. Nisa (2015) menyatakan bahwa petani responden sudah terbiasa sejak masa kecilnya untuk bercocok tanam serta sudah terdidik dalam menganut pola masyarakat setempat.

\section{Faktor Intrinsik Pembentuk Motivasi}

Faktor intrinsik atau sering disebut dengan faktor internal merupakan unsurunsur yang berasal dari dalam diri seseorang yang memberikan dorongan kepada orang tersebut untuk melakukan sesuatu tindakan (Makendra, 2016). Faktor intrinsik terdiri atas 7 variabel, yaitu: umur, pendidikan formal, pendidikan non formal, pengalaman, luas lahan usahatani jahe, pendapatan usahatani jahe, dan jumlah tanggungan keluarga. Secara umum, faktor intrinsik berada kategori sedang dengan persentase skor sebesar 55,24 persen. Tabel 1 menunjukkan distribusi skor dari masingmasing variabel faktor intrinsik.

Tabel 1. Distribusi Skor Variabel Faktor Intrinsik

\begin{tabular}{lccc}
\hline \multicolumn{1}{c}{$\begin{array}{c}\text { Faktor } \\
\text { intrinsik }\end{array}$} & $\begin{array}{c}\text { Jumlah } \\
\text { skor }\end{array}$ & $\begin{array}{c}\text { \% } \\
\text { skor }\end{array}$ & Kategori \\
\hline Umur & 171 & 55,16 & Sedang \\
$\begin{array}{l}\text { Pendidikan } \\
\text { formal }\end{array}$ & 227 & 73,23 & Tinggi \\
$\begin{array}{l}\text { Pendidikan } \\
\text { non formal }\end{array}$ & 81 & 26,13 & Rendah \\
$\begin{array}{l}\text { Pengalaman } \\
\text { Luas lahan }\end{array}$ & 189 & 60,97 & Tinggi \\
$\begin{array}{l}\text { Pendapatan } \\
\text { Jumlah }\end{array}$ & 179 & 57,74 & Sedang \\
tanggungan & 170 & 51,61 & Sedang \\
\hline Faktor intrinsik & 1.177 & 54,84 & Sedang \\
\hline
\end{tabular}

a. Umur

Umur merupakan lama hidup yang dimiliki seseorang. Hasil penelitian menunjukkan kategori sangat tinggi atau usia 15-24 tahun sebanyak 1,61 persen, kategori tinggi atau usia 25-34 tahun 
sebanyak 25,81 persen, kategori sedang atau usia 35-44 tahun sebanyak 37,10 persen, kategori rendah atau usia 45-54 tahun sebanyak 17,74 persen, dan kategori sangat rendah atau usia di atas 54 tahun sebanyak 17,74 persen. Berdasarkan Tabel 1 dapat diketahui bahwa tingkat umur responden berada kategori sedang dengan persentase skor sebesar 55,16 persen. Kondisi ini sudah tergambar dari 37,10 persen responden yang mendominasi kelompok umur 35-44 tahun dimana pada usia ini seseorang dikatakan produktif. Rasyid (2016) menyatakan bahwa petani yang memiliki usia yang lebih muda umumnya memiliki kemampuan fisik yang lebih baik dibandingkan dengan petani yang sudah berusia tua.

\section{b. Pendidikan Formal}

Pendidikan formal merupakan tingkat pendidikan terakhir yang dicapai oleh petani jahe saat menduduki bangku sekolah di lembaga pendidikan formal. Jenjang pendidikan yang dicapai responden, meliputi: perguruan tinggi sebanyak 6,45 persen, SLTA (Sekolah Lanjutan Tingkat Atas) sebanyak 58,06 persen, SLTP (Sekolah Lanjutan Tingkat Bawah) sebanyak 30,65 persen, SD (Sekolah Dasar) sebanyak 4,84 persen, dan tidak ditemukan responden yang tidak pernah bersekolah formal. Berdasarkan Tabel 1 dapat diketahui bahwa tingkat pendidikan formal responden berada kategori tinggi dengan persentase skor sebesar 73,23 persen. Kondisi ini sudah tergambar dari 58,06 persen responden yang mendominasi pada kategori lulusan SLTA (Sekolah Lanjutan Tingkat Atas). Managanta (2016) menyatakan bahwa tingkat pendidikan akan mempengaruhi kemampuan petani dalam mengembangkan usahataninya, dimana pendidikan yang memadai akan mempermudah petani menyesuaikan diri terhadap perkembangan bidang pertanian.

\section{c. Pendidikan Non Formal}

Pendidikan non formal dinilai dari seberapa sering petani jahe mengikuti kegiatan pelatihan sebagai upaya menambah pengetahuan dan skill dalam mengembangkan usahatani jahe yang dijalaninya. Satu tahun terakhir diketahui sebanyak 74,19 persen responden tidak pernah mengikuti kegiatan pelatihan, 22,58 persen responden mengikuti 1 pertemuan kegiatan pelatihan, 1,61 persen responden mengikuti 2 pertemuan kegiatan pelatihan, serta 1,61 persen responden mengikuti 3 pertemuan kegiatan pelatihan. Berdasarkan Tabel 1 dapat diketahui bahwa tingkat pendidikan 
non formal responden petani jahe di Kecamatan Porsea berada kategori rendah dengan persentase skor sebesar 26,13 persen. Kondisi ini sudah tergambar dari 74,19 persen responden yang mendominasi pada kategori tidak pernah mengikuti pelatihan dalam waktu satu tahun terakhir. Sebagian besar responden menyatakan bahwa mereka sangat jarang mendapat informasi mengenai penyelenggaraan pelatihan usahatani khususnya pada komoditas jahe. Sesuai dengan pernyataan Ruhimat (2015) bahwa gambaran rendahnya pendidikan informal di kalangan petani menjelaskan bahwa akses petani dalam memperoleh informasi masih belum cukup baik.

\section{d. Pengalaman}

Pengalaman meliputi lama waktu yang dimiliki responden dalam menjalankan usahatani jahe. Hasil penelitian menunjukkan terdapat 16,13 persen responden berpengalaman di atas usia 15 tahun, 11,29 persen respoden berpengalaman 11-15 tahun, 33,87 persen responden berpengalaman 6-10 tahun, 38,71 persen responden berpengalaman 1-5 tahun, dan tidak ditemukan responden yang berpengalaman di bawah 1 tahun. Berdasarkan Tabel 1 dapat diketahui bahwa tingkat pengalaman responden berada kategori tinggi dengan persentase skor sebesar 60,97 persen. Tingginya pengalaman yang dimiliki responden menggambarkan bahwa mereka sudah terbiasa untuk membudidayakan jahe bahkan sejak masa mudanya. Sesuai data yang diperoleh bahwa sebanyak 20,97 persen responden diketahui memulai usahatani jahe sebelum berusia 25 tahun. Pengalaman bertani yang lama akan membuat petani merasa bahwa usahtani yang dijalaninya adalah cara hidup yang paling tepat dan sesuai dengan dirinya (Nurdina, dkk, 2015).

\section{e. Pendapatan}

Pendapatan meliputi pencapaian yang diperoleh petani dari penjualan hasil panen jahe dalam satu periode tanam. Hasil penelitian menunjukkan terdapat 8,06 persen responden memiliki pendapatan kategori sangat tinggi yaitu lebih dari Rp80.000.000, 25,81 persen responden memiliki pendapatan kategori tinggi yaitu Rp40.000.001 s/d Rp80.000.000, 22,58 persen responden memiliki pendapatan kategori sedang yaitu Rp20.000.001 s/d Rp40.000.000, 33,87 persen responden memiliki pendapatan kategori rendah yaitu Rp4.000.001 s/d Rp20.000.000, dan 9,68 persen responden memiliki pendapatan 
kategori sangat rendah yaitu kurang dari Rp4.000.000. Tabel 1 menunjukkan bahwa tingkat pendapatan responden dari usahatani jahe berada kategori sedang dengan persentase skor sebesar 57,74 persen. Pendapatan seorang petani jahe akan selalu berubah-ubah karena disesuaikan hasil produksi yang diperoleh dan hal paling utama harga pasar yang fluktuatif. Pendapatan sangat berpengaruh kepada kelangsungan usahatani di masa depan karena sebagai acuan modal untuk penanaman di periode berikutnya (Primadesi, 2010).

\section{f. Luas Lahan}

Luas lahan mencakup ukuran lahan atau tanah yang dimanfaatkan sebagai media penanaman komoditas jahe. Hasil penelitian menunjukkan terdapat 1,61 persen responden memiliki luas lahan jahe kategori sangat tinggi $\left(>10.000 \mathrm{~m}^{2}\right)$, 16,13 persen responden memiliki luas lahan kategori tinggi $\left(5.000 \mathrm{~m}^{2} \mathrm{~s} / \mathrm{d}\right.$ $\left.10.000 \mathrm{~m}^{2}\right), 27,42$ persen responden memiliki luas lahan kategori sedang $\left(2.500 \mathrm{~m}^{2}-5.000 \mathrm{~m}^{2}\right), 48,39$ persen responden memiliki luas lahan kategori rendah $\left(500 \mathrm{~m}^{2}-2.500 \mathrm{~m}^{2}\right)$, dan 6,45 persen responden memiliki luas lahan kategori sangat rendah $\left(<500 \mathrm{~m}^{2}\right)$. Tabel 1 menunjukkan bahwa tingkat luas lahan yang digunakan responden untuk usahatani jahe berada pada kategori sedang dengan persentase skor sebesar 51,61 persen. Rata-rata luas lahan jahe yang dimiliki responden adalah sekitar $3.322,58 \mathrm{~m}^{2}$ dengan lahan tersempit sebesar $400 \mathrm{~m}^{2}$ dan lahan terluas sebesar $14.000 \mathrm{~m}^{2}$. Sofwan, et al (2018) mengatakan bahwa luas penguasaan lahan adalah salah satu faktor yang sangat berpengaruh terhadap pencapaian jumlah produksi komoditas yang dibudidayakan seorang petani. Lahan yang luas akan membuka peluang untuk mendapatkan hasil produksi yang lebih banyak dan sebaliknya lahan yang sempit akan menutup kemungkinan mendapatkan hasil produksi yang banyak. g. Jumlah Tanggungan Keluarga Jumlah tanggungan keluarga merupakan banyaknya anggota keluarga yang ditanggung seorang kepala keluarga Hasil penelitian menunjukkan terdapat 3,23 persen responden memiliki jumlah tanggungan kategori sangat tinggi $(>6$ orang), 16,13 persen responden memiliki jumlah tanggungan pada kategori tinggi (5-6 orang), 45,16 persen responden memiliki jumlah tanggungan pada kategori sedang (3-4 orang), 22,58 persen responden memiliki jumlah tanggungan kategori rendah (1-2 orang), dan 12,90 persen responden diketahui tidak 
memiliki tanggungan keluarga. Tabel 1 menunjukkan bahwa tingkat jumlah tanggungan keluarga yang dimiliki responden berada kategori sedang dengan persentase skor sebesar 54,84 persen. Kondisi ini sudah tergambar dari 45,16 persen responden yang mendominasi kategori jumlah tanggungan keluarga sebanyak 3-4 orang. Wiweka, et al (2018) menyatakan bahwa semakin banyak jumlah anggota keluarga akan mendorong seorang kepala keluarga untuk bekerja agar dapat memenuhi kebutuhan seluruh anggota rumah tangganya.

\section{KESIMPULAN DAN SARAN}

\section{Kesimpulan}

1. Penelitian didominasi oleh responden berumur produktif (15-64 Tahun) sebanyak 95,16 persen, berjenis kelamin laki-laki sebanyak 93,55 persen, lulusan pendidikan tingkat SLTA sebanyak 58,06 persen, dan pekerjaan utama sebagai petani sebesar 77,42 persen.

2. Faktor intrinsik berada pada kategori sedang dengan persentase skor sebesar 55,16 persen.

\section{Saran}

1. Pendidikan non formal perlu ditingkatkan melalui pelaksanaan kegiatan pelatihan ataupun penyuluhan pertanian oleh pemerintah Kecamatan Porsea dan Dinas Pertanian Kabupaten Toba secara rutin. Tujuannya adalah untuk membantu memperluas wawasan dan keterampilan petani jahe terkait usahatani jahe. Diharapkan kepada lembaga penyuluh pertanian dapat memberikan kepastian jadwal pertemuan dengan petani jahe secara rutin dan pengurus kelompok tani setempat dapat membantu menyampaikan informasi penyuluhan secara merata kepada petani.

2. Pemerintah setempat diharapkan dapat memberikan dukungan kepada petani jahe dengan memberikan informasi pasar secara rutin dan membantu petani yang mengalami kesulitan dalam pengajuan peminjaman modal di lembaga permodalan setempat.

\section{DAFTAR PUSTAKA}

Badan Pusat Statistik (BPS). 2019. Provinsi Sumatera Utara dalam Angka 2019. Sumatera Utara: Badan Pusat Statistik Provinsi Sumatera Utara.

Badan Pusat Statistik (BPS). 2021. Kabupaten Toba Samosir dalam Angka 2021. Toba Samosir: Badan 
Pusat Statistik Kabupaten Toba Samosir.

Badan Pusat Statistik (BPS). 2021. Provinsi Sumatera Utara dalam Angka 2021. Sumatera Utara: Badan Pusat Statistik Provinsi Sumatera Utara.

British Medical Association. 2020. BMJ Best Parctice Coronavirus Disease 2019 (COVID-19). Diakses dari https://bestpractice.bmj.com/topics/ en-gb/3000201 pada tanggal 05 April 2021.

ÇİFCI, et al. 2018. Ginger (Zingiber officinale) Prevents Severe Damage to The Lungs Due to Hyperoxia and Inflammation. TUBITTAK Turkish Journal of Medical Sciences, Vol. 48, p. 892-900.

Guo, et al. 2020. The Origin, Transmission and Clinical Therapies on Coronavirus Disease 2019 (COVID-19) Outbreak-An Update on The Status. MMR Military Medical Research, Vol. 7, No. 11, p. 1-10.

Ibrahim, Jamaluddin, \& Arsyad Lubis. 2012. Motivasi Petani dalam Keragaan Teknologi Sistem Usaha Tani Padi Sawah di Kecamatan Pengabuan Kabupaten tanjong Jabung Barat. Sosio Ekonomika Bisnis, p. 23-32.

Kusumawanti, Ratih. 2020. HORTIKULTURA KEMENTAN: Kebutuhan Benih Jahe Meningkat Drastis. PORTONEWS. Diakses dari

https://www.portonews.com/2020/k euangan-dan-

portfolio/perdagangan-danjasa/hortikultura-kementankebutuhan-benih-jahe-meningkatdrastis/ pada tanggal 27 Mei 2021.

Makendra, Nanda. 2016. Motivasi Petani dalam Usahatani Tanaman Bunga Krisan di Desa Hargobinangun Kecamatan Pakem Kabupaten
Sleman. Skripsi Program Studi Agribisnis, Fakultas Pertanian, Universitas Muhammadiyah Yogyakarta.

Managanta, Andri Amaliel. 2016. Motivasi dan Persepsi Petani Padi Terhadap Intensi Penggunaan Pupuk Organik di Desa Leuwibatu Kecamatan Rumpin Kabupaten Bogor. Jurnal AgroPet, Vol. 13, No. 2, p. 1-20.

Nisa, Naning Khoirun. 2015. Motivasi Petani dalam Menanam Komoditas pada Daerah Lumbung Padi di Kabupaten Gresik. Swara Bhumi, Vol. 3, No. 3, p. 80-90.

Nurdina, Insani Fahma, Asihing Kustanti, \& Rudi Hilmanto. 2015. Motivasi Petani dalam Mengelola Hutan Rakyat di Desa Sukoharjo 1 Kecamatan Sukoharjo Kabupaten Pringsewu. Jurnal Sylva Lestari, Vol. 3, No. 3, p. 51-62.

Pramudya, Adi. 2016. Budi Daya Bisnis Jahe Adi "Si Anak Rempah". Jakarta: PT Agromedia Pustaka.

Primadesi, Febriana. 2010. Motivasi Petani dalam Budidaya Tanaman Buah Naga (Hylocereus Sp.) di Kecamatan Bendosari Kabupaten Sukoharjo. Skripsi Program Studi Penyuluhan dan Komunikasi Pertanian, Fakultas Pertanian, Universitas Sebelas Maret Surakarta.

Rasyid, Siti Aisyah. 2016. Motivasi Petani dalam Berusahatani Kakao Dusun Koroha Desa Tamboli Kecamatan Samaturu Kabupaten Kolaka. Skripsi Program Studi Agribisnis, Fakultas Pertanian, Universitas Muhammadiyah Makassar.

Restutiningsih, et al. 2016. Motivasi Petani dalam Berusahatani Hortikultura di Desa Wisata Candikuning, Kecamatan Baturiti, Kabupaten Tabanan. E-Jurnal 
Agribisnis dan Agrowisata, Vol. 5, No. 1.

Ruhimat, Idin Saepudin. 2015. Tingkat Motivasi Petani dalam Penerapan Sistem Agroforestry. Jurnal Penelitian Sosial dan Ekonomi Kehutanan, Vol. 12, No. 2, p. 1-11.

Sofwan, et al. 2018. Motivasi Petani, Faktor Pendorong dan Faktor Penghambat dalam Budidaya Tanaman Cengkeh di Mukim Lampuuk Kecamatan Lhoknga Kabupaten Aceh Besar. Jurnal Ilmiah Mahasiswa Pertanian, Vol. 3, No. 4, p. 355-367.

Suherdi, Siti Amanah, \& Pudji Muljono. 2014. Motivasi Petani dalam Pengelolaan Usaha Hutan Rakyat Desa Cingambulm Kecamatan Cingambul, Majalengka. Jurnal Penyuluhan, Vol. 10, No. 1, p. 8593.
Wiweka, et al. 2018. Motivasi Petani dalam Membudidayakan Tanaman Pepaya Calina (Carica papaya L) (Kasus Kelompok Tani Pepaya Calina di Desa Sulangai, Kecamatan Petang, Kabupaten Badung). E-Jurnal Agribisnis dan Agrowisata, Vol. 7, No. 3.

Poerwadarminta, W. J. S. 2011. Kamus Umum Bahasa Indonesia (Susunan W. J. S. Poerwadarminta, Diolah kembali oleh Pusat Bahasa, Departemen Pendidikan Nasional. Edisi III, Cet. 4. Jakarta: Balai Pustaka. 